NOTICE: this is the author's version of a work that was accepted for publication in Resources, Conservation and Recycling. A definitive version was subsequently published in Resources Conservation and Recycling 48, 26-40, 2006. http://dx.doi.org/10.1016/j.resconrec.2005.11.004

(c) 2015, Elsevier. Licensed under the Creative Commons Attribution-NonCommercial-NoDerivatives 4.0 International http://creativecommons.org/licenses/by-nc-nd/4.0.

\title{
Environmental systems analysis of the use of bottom ash from incineration of municipal waste for road construction
}

\author{
Susanna Olsson $^{\mathrm{a}} *$ Erik Kärrman $^{\mathrm{b}}$ and Jon Petter Gustafsson ${ }^{\mathrm{a}}$
}

${ }^{a}$ Department of Land and Water Resources Engineering, Royal Institute of Technology (KTH), SE-100 44 Stockholm, Sweden.

${ }^{\mathrm{b}}$ Ecoloop AB, Brännkyrkagatan 35, 11822 Stockholm, Sweden.

* Corresponding author. Tel.: +46 879073 28; Fax: +46 8411 0775; E-mail: Susannao@kth.se. 


\section{Abstract}

Bottom ash, originating from municipal solid waste incineration (MSWI), is a potential road construction material. The aim of this study was to describe what differences in resource use and emissions that can be expected if crushed rock in the sub-base of a road in the Stockholm region in Sweden were to be substituted by MSWI bottom ash, taking into account the whole life cycle of the road and including alternative disposal of the bottom ash. An environmental systems analysis approach based on a life cycle perspective was outlined and used in a case study. It was found that the studied alternatives would cause different types of potential environmental impact; whereas crushed rock in the road's sub-base would lead to larger use of resources, the alternative with MSWI bottom ash in the sub-base would lead to larger contaminant leaching. The results are sensitive to the transport distance for the road material and to conditions affecting the leaching from the road. The differences between energy uses in the two alternatives derive mainly from production of crushed rock and from landfilling of MSWI bottom ash whereas the metal emissions occur in the use stage of the road's life cycle.

Keywords: Environmental impact, disposal, LCA, waste management, MSWI bottom ash 


\section{Introduction}

Swedish environmental objectives call for an increased recycling of resources. One possibility discussed during the last decade is to recycle bottom ash from municipal solid-waste incineration (MSWI) as a road construction material. Previous research on the technical properties of MSWI bottom ash has shown that this material can meet the technical requirements for an unbound sub-base layer in a road (Arm, 2003). In Sweden up to 400000 tonnes of MSWI bottom ash material are formed annually and disposal of this material is resource consuming. In addition, the space at existing landfills is limited and it is hard to find new suitable areas for waste disposal. Use of bottom ash in road constructions would enable less disposal of bottom ash and at the same time the amounts of rock extracted for road building purposes would be reduced.

Apart from being acceptable from a geotechnical perspective, it has to be proven that the material is environmentally friendly if it is to be used in road constructions. Traditionally, environmental assessments of MSWI bottom ash in constructions have focused on leaching aspects (Olsson, 2005). In particular, the chemical properties and leaching mechanisms of the material has been thoroughly investigated (i.e. Wiles, 1996; Chandler et al., 1997; Fällman, 1997; Meima et al., 1999; Meima et al., 2002). In some cases, the potential leaching from the material in field settings (Fällman et al., 1994), or more specifically, in road constructions (Hartlén et al., 1999; BruderHubscher et al., 2001) has been estimated and frameworks for risk assessments and critical limit definition has also been developed (i.e. Kosson et al., 2002; Apul et al., 2003; Petkovic et al., 2004) . 
However, while much emphasis has been placed on risks of contaminant leaching, little attention has been paid to other kinds of impact, such as resource use and emissions that do not originate from the road material. To discuss the use of resources and environmental impact from a wider perspective, an environmental systems analysis (ESA) approach may be useful. Such an analysis would provide a tool for strategic environmental assessment (SEA), which is required for strategic decision making according to EU-directive 2001/42/EG. Roth and Eklund (2003) argue that current leaching tests only forms the first level of environmental assessment for alternative materials and that it should be complemented by the broader system boundaries used in substance flow studies and in life cycle assessments (LCA). This would be particularly important when there is a conflict between different environmental impacts. In another study (Tossavainen et al., 1999) LCA is also suggested as a method to assess the environmental impact of alternative road construction materials.

There are a few cases where this approach has been used for evaluation of alternative materials in road constructions. In Denmark, a model for LCA of road construction and disposal of MSWI residues has recently been developed (Birgisdottir, 2005). In Finland, Mroueh et al. (2001) used a life cycle perspective to assess the environmental impact from alternative road and earth constructions. They found that the use of by-products as a substitute for natural aggregates could reduce the environmental impact for some impact categories. However, the project did not include MSWI bottom ash. No similar studies have been found that address the utilization of MSWI bottom ash in road constructions for Swedish conditions. For 
other parts of the waste management system (i.e. the handling of municipal solid waste) the LCA approach has shown to be a useful tool for assessing environmental impacts (i.e. Björklund et al., 1999; Finnveden et al., 2005).

So far, bottom ash has not been used for road construction to any great extent in Sweden. One reason is that analyses of the environmental consequences of substituting crushed rock for ash have mainly focused on contaminant leaching from the material. Other aspects such as resource use and emissions to air have attracted limited interest. There is a need for more knowledge of what environmental aspects can be expected and how significant they are in relation to each other and to the potential leaching.

The aim of this study is to describe the differences in resource use and emissions that can be expected if crushed rock in the sub-base of a road in the Stockholm region in Sweden were to be substituted by MSWI bottom ash. Questions that the study addresses are how the alternatives differ and which processes are of significance for the difference. An ESA approach, based on the concept of LCA, was used to describe the system and to quantify its resource use and emissions.

\section{Method}

\subsection{Environmental systems analysis}

ESA is a method to describe environmental impact of a system from a holistic point of view, including all subsystems and their interrelations. The use of this approach, 
instead of analyzing subsystems as isolated parts, can provide information that helps to avoid sub-optimizations in decision situations. A life cycle perspective was chosen, since different environmental impacts are likely to occur in different stages of the life cycle of a road. Thus, this study was performed as an environmental systems analysis, based on the concepts of life cycle thinking and using the framework of LCA.

Firstly, the scope of the study and the system boundaries were defined and a conceptual model of the studied system was constructed. This was followed by an inventory quantifying the resources that would be used and the emissions that would be formed in each life cycle stage. These flows into or out of the system are here referred to as 'aspects'. Finally, the results were interpreted and the alternatives were compared. To obtain the relative magnitude of each aspect, the result was normalized by relating each substance or energy flow with the same kind of flow on a national basis. Sensitivity analyses were continuously made, and those aspects that were of significance for the result were further investigated. A detailed description of the LCA procedure can be found in (ISO, 1997).

\subsection{Studied scenarios}

According to Arm (2003) MSWI bottom ash can be used in the sub-base layer of a moderately busy road; thus such an application was considered in the ESA. The study was made as a case study, where information and experiences from a test road, Törringevägen in southern Sweden, were applied on a theoretical case in the Stockholm region. Törringevägen, situated outside Malmö, was built in 1998 as a test road and is divided into a number of sections with different materials (Hartlén et al., 
1999; Arm, 2003). MSWI bottom ash was used in the sub-base in one of these sections, and crushed rock in another.

Two alternative potential scenarios were analyzed and compared in terms of resource use and emissions. Since the presence of MSWI bottom ash in the sub-base layer requires a somewhat thicker base course layer, both these layers were included in the study (Figure 1). In the first case, crushed rock was used as an unbound sub-base material in the theoretical road. In the second case, the crushed rock in the sub-base was substituted for bottom ash in the same road. In both cases crushed rock was used in the base course layer. The thickness was set to $465 \mathrm{~mm}$ for the sub-base and $80 \mathrm{~mm}$ and $150 \mathrm{~mm}$ for the base course of alternative 1 and 2 respectively.

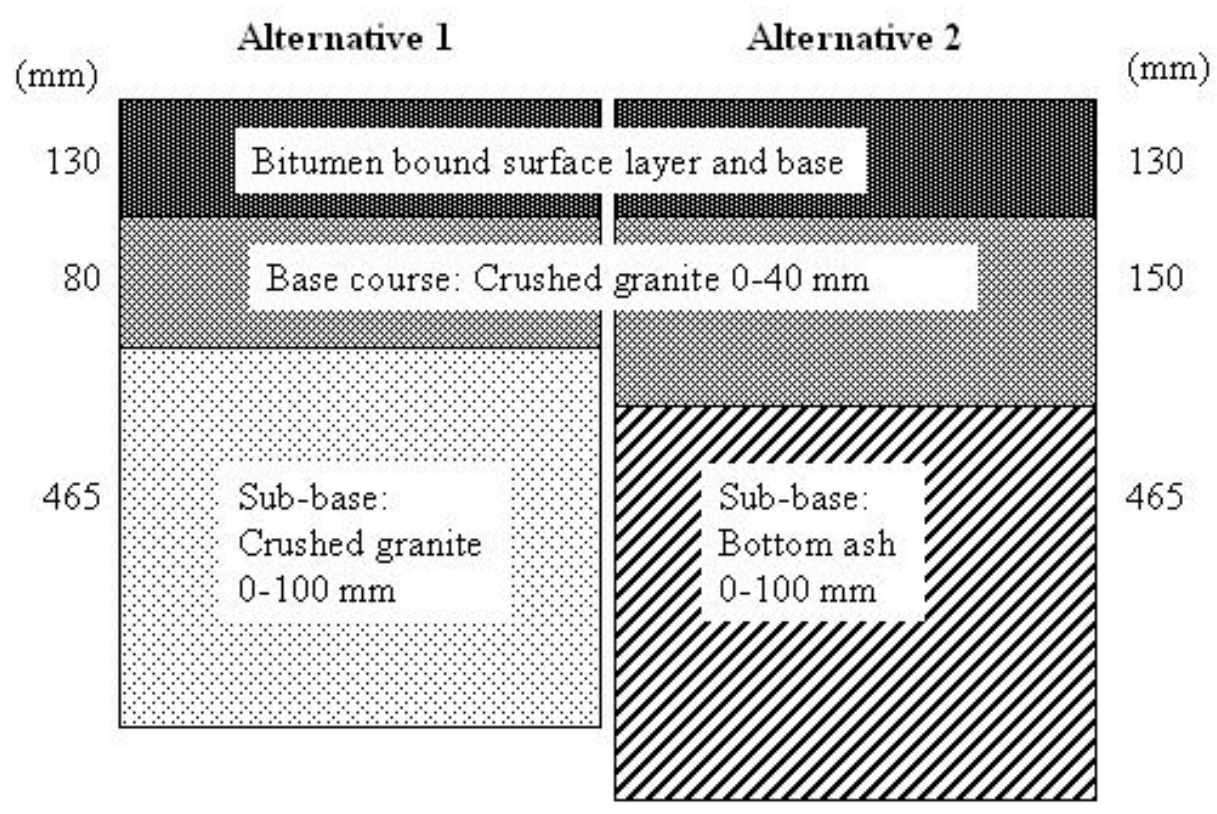

Fig. 1. Cross-section of the theoretical road, all physical properties the same as the test road Törringevägen. 


\subsection{System boundaries}

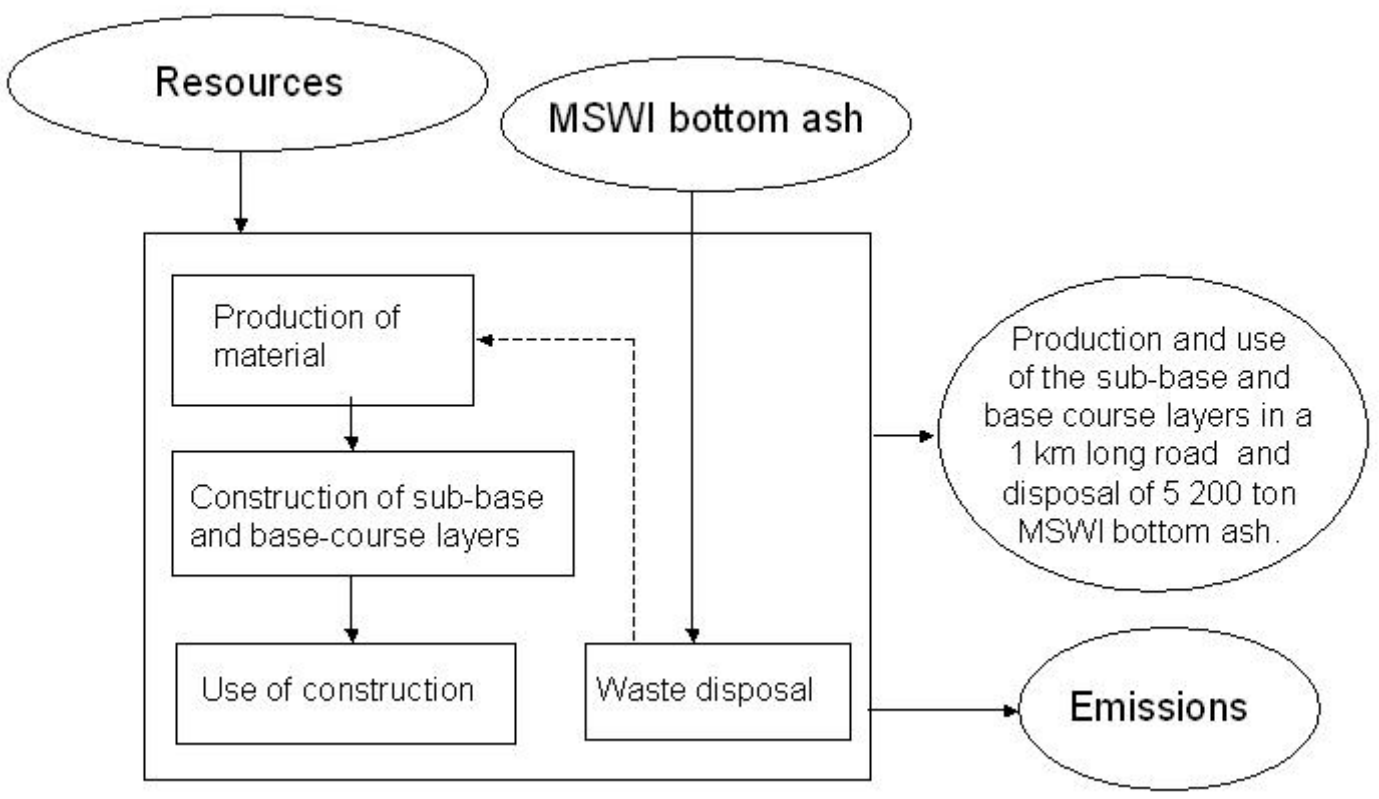

Fig. 2. System boundaries and life cycle stages taken into account.

The study includes all the significant life-cycle stages of the base course and the subbase layers as identified by Mroueh et al. (2000), covering the production and transportation of materials, their location in the road structure and the use of the road. In addition, the system also includes disposal of MSWI bottom ash as a life cycle stage. This enables evaluation of how the utilization of bottom ash may impact the overall environmental performance of the system. By including disposal of MSWI bottom ash the effects of less landfilling can be considered. This system design means that the system produces two services, firstly the sub-base and the base course layers of a $1 \mathrm{~km}$ road (all physical properties the same as Törringevägen), and secondly the disposal of a certain amount of MSWI bottom ash (Figure 2). Since road materials often remain in place even when the road is no longer in use, a demolition stage has not been included. All parts of the system that were similar in both alternatives were excluded from the study. The result will therefore not show the total environmental 
impact caused by each alternative. This was considered as a relevant limitation in view of the aim of the study, since it increases the focus on the differences between the alternatives.

Resources (including energy) and MSWI bottom ash are flows that enter the system, and emissions leave the system. Flows with the potential to affect any of the impact categories described by SETAC-Europe (1999) were considered as environmental aspects and were quantified during the inventory step. Other criteria for the choice of aspects were that there should be available data to enable quantification and that the aspects should be significant for the result of the study. As a result of these criteria the environmental aspects included in this study were use of resources (natural aggregates and energy), emissions to air $\left(\mathrm{SO}_{2}, \mathrm{NO}_{\mathrm{x}}, \mathrm{CO}, \mathrm{CO}_{2}, \mathrm{HC}, \mathrm{CH}_{4}, \mathrm{VOC}, \mathrm{N}_{2} \mathrm{O}\right.$ and particles) and emissions to water (COD, N-tot, Oil, Phenol, As, Cd, Cr, Cu, Ni, Pb and $\mathrm{Zn})$.

This means that use of machinery and human resources, as well as occupation of land area, were not considered. The processes that would be most important for the difference in land area occupation between the alternatives are probably the extraction and crushing of rock and the land area required for landfill disposal. Other excluded environmental aspects were the energy and material used for final covering of the landfill, dust, noise, and leaching of some substances (i.e. $\mathrm{Mo}, \mathrm{SO}^{2-}$ and $\mathrm{Cl}^{-}$). Waste formation and use and production of chemicals for leachate treatment on the landfill were neglected on the basis of a preliminary assessment of their quantity and significance for the result. 


\subsection{Inventory}

For all life cycle stages that differed between the two scenarios, data were gathered for the use of major resources and the environmental hazardous emissions to air and water (Figure 3).

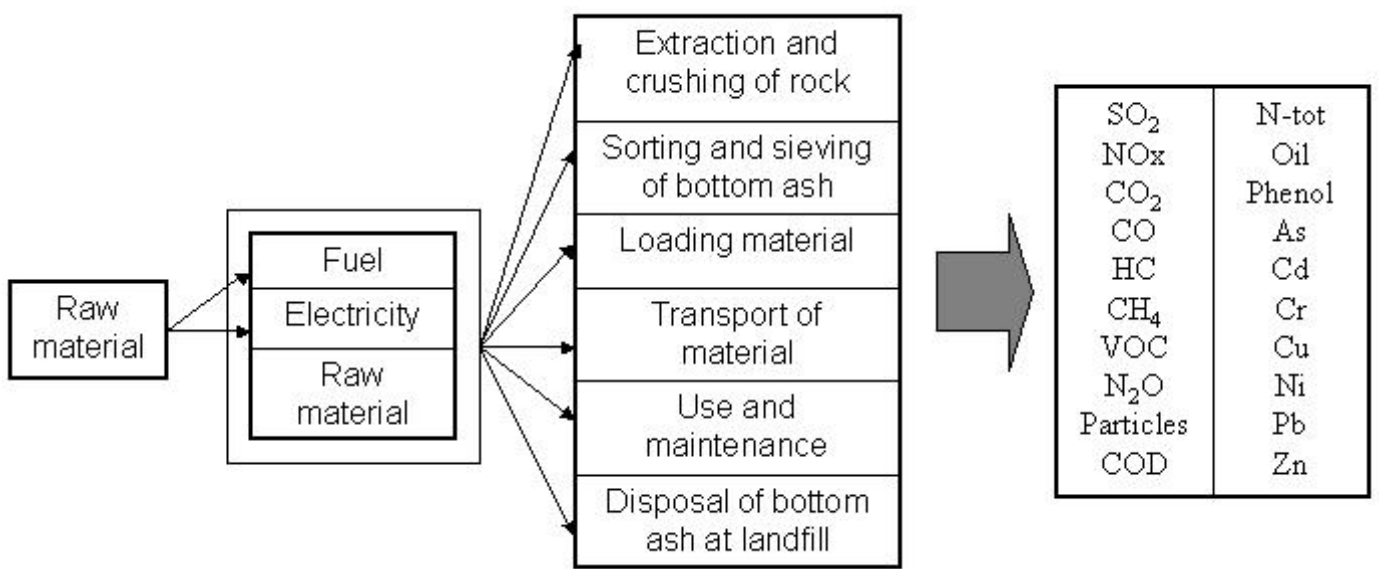

Fig. 3. Resources and emissions investigated for the life cycle stages of the studied road.

For these aspects we intended to assemble data that were representative for the Stockholm region and as currently valid as possible. No data older than from 1990 were used. Most data were average values for Sweden. Transport distances may vary depending on where in the country the road is built. In the studied case, the transport distance was assumed to be $20 \mathrm{~km}$ for both bottom ash and crushed rock. The road material was assumed to be transported with a 32-tonne truck, returning empty. A sensitivity analysis was carried out for different transportation distances, to examine the impact of transportation distance on the total energy use of the system. 
Data were obtained from the literature and by interviews with people working in the sector. General data on road building and production of material were based mainly on results from Stripple (2001) and on interviews. The crushed rock was assumed to be produced in a quarry. Information on the disposal of MSWI bottom ash was found in different studies (Tillman et al., 1991; Mingarini, 1996; Sundqvist et al., 1997; Björklund, 1998). For the use of fuel, pre-combustion values for fuel production has been included, according to Stripple (2001). All data are of course uncertain to varying extents. Leaching of metals was estimated from leaching tests results. Two types of data were used: potentially available metals measured by using NT ENVIR 003 method (Tossavainen et al., 1999; RVF, 2002) and leached metals measured in CEN test (EN 12457-3) with a liquid-solid (L/S) ratio of 2 (Tossavainen et al., 1999; RVF, 2002).

\section{Results}

\subsection{Differences in resource use and emissions}

The alternatives would differ in their resource use and emissions, as can be seen in

Table 1. Alternative 1, where rock material is used in the sub-base, would use larger amounts of energy and crushed rock than alternative 2, where MSWI bottom ash is used in the sub-base. While the rock material is used during the construction stage (as a construction material), the energy is used for various purposes in all the different life cycle stages. The processes causing the most energy use will be further discussed below. The energy used is mainly derived from fossil fuel. 
Table 1. Potential flows of substances from $1 \mathrm{~km}$ of the two alternatives. Both alternatives should be seen relative to each other; the figures should not be interpreted as the total flows, since only those life cycle stages where environmental impact differs between alternatives have been included. In alternative 1 crushed rock is used in the road's sub-base and MSWI bottom ash is disposed of on a landfill. In alternative 2 the MSWI bottom ash is used in the road instead of being landfilled.

\begin{tabular}{|c|c|c|c|c|c|c|}
\hline $\begin{array}{c}\text { Environmental } \\
\text { aspect }\end{array}$ & Alternative 1 & Alternative 2 & Unit & $\begin{array}{l}\text { Difference } \\
\text { (alt. 1-alt. 2) }\end{array}$ & $\begin{array}{c}\text { National } \\
\text { values (unit } \\
\text { per person) }\end{array}$ & $\begin{array}{c}\text { Normalized } \\
\text { difference } \\
\text { (alt. } 1 \text { - alt. 2) }\end{array}$ \\
\hline \multicolumn{7}{|l|}{ Resource use $^{1}$} \\
\hline Energy & 0.93 & 0.37 & $\mathrm{TJ}$ & 0.56 & 0.25 & 2.3 \\
\hline \begin{tabular}{|l|} 
Natural \\
aggregates
\end{tabular} & 7600 & 2100 & tonnes & 5500 & 4.4 & 1300 \\
\hline \multicolumn{7}{|l|}{ Emissions to air ${ }^{2}$} \\
\hline $\mathrm{SO}_{2}$ & 20 & 9.0 & $\mathrm{~kg}$ & 11 & 6.5 & 1.8 \\
\hline $\mathrm{NO}_{\mathrm{x}}$ & 350 & 150 & $\mathrm{~kg}$ & 200 & 27 & 7.5 \\
\hline $\mathrm{CO}$ & 45 & 21 & $\mathrm{~kg}$ & 24 & 86 & 0.28 \\
\hline $\mathrm{CO}_{2}$ & 41000 & 18000 & $\mathrm{~kg}$ & 23000 & 6200 & 3.7 \\
\hline $\mathrm{HC}$ & 24 & 9.9 & $\mathrm{~kg}$ & 15 & No data & No data \\
\hline $\mathrm{CH}_{4}$ & 0.05 & 0.02 & $\mathrm{~kg}$ & 0.03 & 630 & 0.000047 \\
\hline VOC & 0.18 & 0.06 & $\mathrm{~kg}$ & 0.12 & 670 & 0.00018 \\
\hline $\mathrm{N}_{2} \mathrm{O}$ & 0.88 & 0.38 & $\mathrm{~kg}$ & 0.50 & 930 & 0.00053 \\
\hline Particles & 12 & 4.2 & $\mathrm{~kg}$ & 8.0 & 9.7 & 0.82 \\
\hline \multicolumn{7}{|l|}{$\begin{array}{l}\text { Emissions to } \\
\text { water }^{3}\end{array}$} \\
\hline COD & 0.61 & 0.27 & $\mathrm{~kg}$ & 0.34 & 56 & 0.0061 \\
\hline N-tot & 0.10 & 0.04 & $\mathrm{~kg}$ & 0.05 & 2.8 & 0.019 \\
\hline Oil & 200 & 90 & $\mathrm{~g}$ & 110 & No data & No data \\
\hline Phenol & 290 & 130 & g & 160 & No data & No data \\
\hline As & 59 & 40 & g & 19 & No data & No data \\
\hline $\mathrm{Cd}$ & 1.8 & 21 & g & -20 & 0.070 & -270 \\
\hline $\mathrm{Cr}$ & 7.6 & 210 & $\mathrm{~g}$ & -200 & 1.4 & -140 \\
\hline $\mathrm{Cu}$ & 84 & 2100 & g & -2000 & 20 & -100 \\
\hline $\mathrm{Ni}$ & 41 & 84 & g & -43 & 1.4 & -30 \\
\hline $\mathrm{Pb}$ & 4.8 & 22 & g & -17 & 4.3 & -4.0 \\
\hline Zn & 50 & 120 & g & -68 & 49 & -1.4 \\
\hline
\end{tabular}

${ }^{1)}$ National values are based on official statistics 2003 for the use of energy and the use of ballast material in the Swedish construction sector (Andersson et al., 2003; SGU, 2003). These values are divided by the total number of inhabitants in Sweden.

${ }^{2)}$ National values are based on official statistics for emissions to air (Feldhusen et al., 2004;

Hammarskjöld et al., 2004). These values are divided by the total number of inhabitants in Sweden. ${ }^{3)}$ Leaching from the road material is estimated from CEN-tests with L/S ratio 2 (Tossavainen et al., 1999; RVF, 2002). National values are based on official statistics 2000 for emissions from municipal waste water treatment plants, pulp and paper industry and some other coastal-based industry in Sweden for COD and N-tot (Brånvall et al., 2002). These values are divided by the total number of inhabitants in Sweden. For the metals the normalization is based on emissions per person in the Stockholm region (Bergbäck et al., 2001). 
Furthermore, alternative 1 would generate more emissions of all types except for the metals. This can be explained by the difference in energy use. All investigated emissions, except the release of As and metals, are caused by energy use. Since alternative 1 uses most energy, this alternative also causes most energy-dependent emissions. The emissions of As and metals, on the other hand, are caused by leaching from the road material. Based on leaching tests with an L/S ratio of 2 it can be expected that alternative 2 (where the MSWI bottom ash is in the road) would result in larger emissions than alternative 1 for the metals, but not for As. The leachate from the landfill was assumed to be treated so that no contaminants could reach the surroundings. Thus, the contaminant leaching from the system only comes from the road during the use stage of the life cycle.

To enable comparisons between the alternatives, data on all flows were normalized by division with the national flow of each kind per person in Sweden. These figures can be seen as an indication of what is large and what is small, in relation to national values on resource use and emissions per person. The normalization results in table 1 show that some environmental aspects may be considered as more important than the others. The use of energy and natural aggregates, the release of metals and As, and the emissions of $\mathrm{NO}_{\mathrm{x}}, \mathrm{CO}_{2}$ and $\mathrm{SO}_{2}$ were of greater significance than the other flows, if compared to flows per person on a national level. These environmental aspects have the potential to cause different kinds of environmental impact. Emissions of metals may cause human toxicity and ecological toxicity. Further, emissions of $\mathrm{CO}_{2}$ may cause climate change, emissions of $\mathrm{SO}_{2}$ may cause acidification and human toxicity 
and emissions of $\mathrm{NO}_{\mathrm{x}}$ may cause acidification, human toxicity, eutrophication and photochemical ozone formation.

\subsection{Energy use in the life cycle stages}

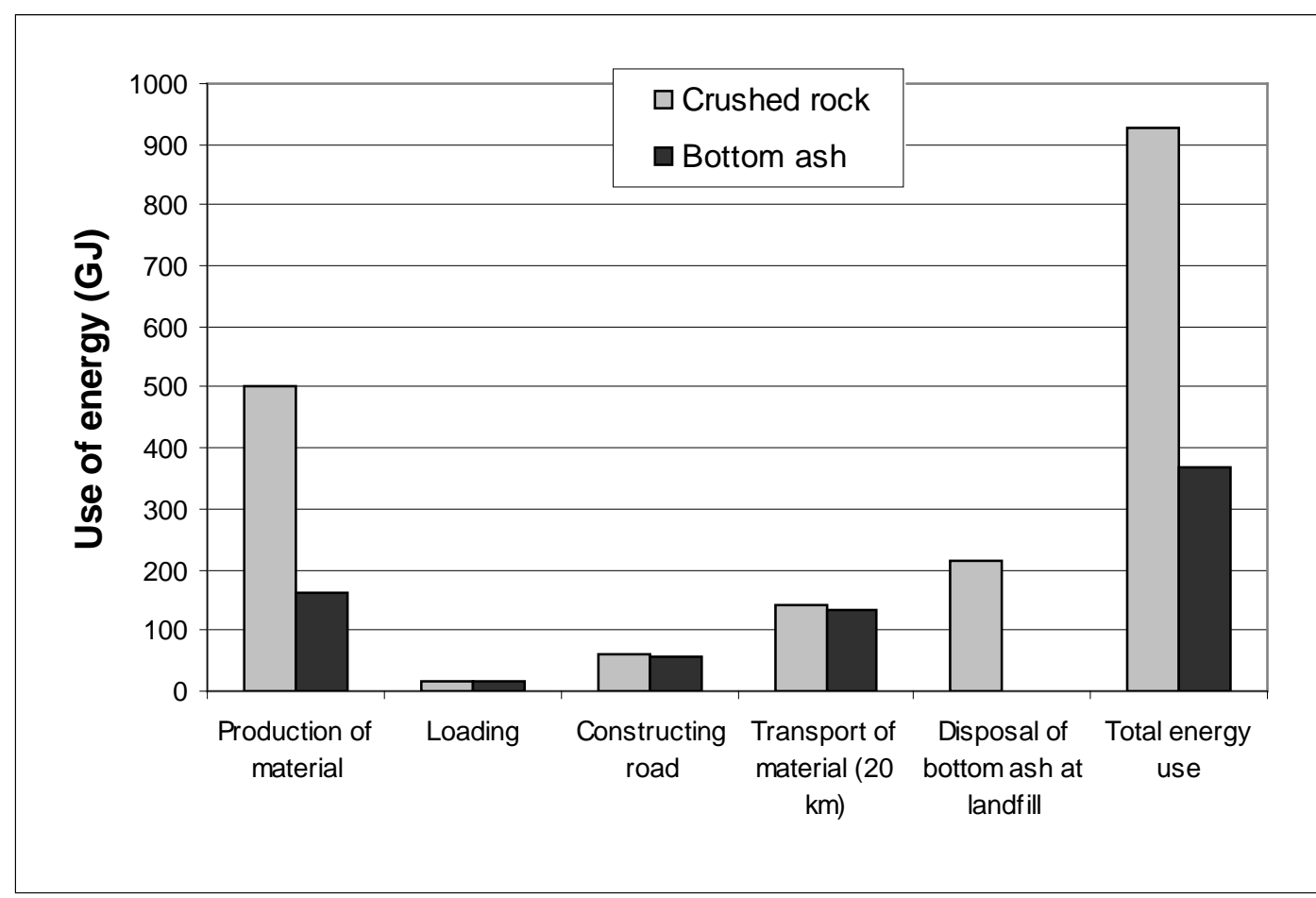

Fig. 4. Use of energy by each life cycle stage in the system. In alternative 1 crushed rock is used in the road's sub-base and MSWI bottom ash is disposed of on a landfill. In alternative 2, the MSWI bottom ash is used in the road instead of being landfilled.

All emissions to air, and to some extent the emissions to water, depend on the amount of energy used during the different life cycle stages. In addition, energy is one of the main resources used by the system. Hence the energy consumption in the different stages is important for their relative contribution to the overall environmental impact of each alternative. As can be seen in Figure 4, the largest difference in energy use between the two alternatives was caused by the fuel and electricity used for producing 
crushed rock. The second greatest difference was related to landfilling of MSWI bottom ash.

The transport distance was assumed to be $20 \mathrm{~km}$ for both MSWI bottom ash and for the crushed rock in the case study. For crushed rock this is a likely transport distance if the rock is transported from a quarry. The transport distance for MSWI bottom ash, on the other hand, is a parameter that may vary considerably between different road projects, since the material is taken from a limited amount of sources. A sensitivity analysis was therefore performed for different transport distances for the MSWI bottom ash. It was shown that since alternative 2 would use considerably less energy in all other life cycle stages, it may include a longer transportation distance and still be the more energy saving alternative. However, if the MSWI bottom ash had to be transported more than $140 \mathrm{~km}$, alternative 2 would use more energy than alternative 1. Hence, the transport distance was an important parameter for the outcome of the comparison.

\subsection{Leaching from the road material}

Accumulated leaching of metals was estimated from CEN tests with an L/S-ratio of 2 and from tests for available content of the metals and As, to illustrate two different time perspectives. A low L/S-ratio allows little water to come in contact with the material and can therefore be used to illustrate the accumulated leaching in a shortterm perspective. If the amount of water in contact with the ash is assumed to be the only parameter that determines leaching, and if water infiltration through the road is assumed to be $15 \mathrm{~mm}$ per year, the leaching at an L/S-ratio of 2 may be approximated 
as equivalent to the accumulated leaching from the road in a 100 -year period. There are, however, few data available on what infiltration rate can be expected in a road of the type studied in this case and it is also likely that the water will be heterogeneously distributed, so that some ash would not be in contact with the water at all. Even though the time perspectives corresponding to the two test methods are uncertain, the results in figure 1 may be seen as leaching in a shorter-term perspective than leaching approximated from availability tests. The content of available metals and As may be seen as an approximation of the accumulated leaching when all possible leaching has occurred, thus corresponding to leaching in an infinite time perspective.

As shown in Figure 5a-b, there would be considerably more leaching of contaminants from the road construction if the available content is used in the comparison, instead of the results from tests with L/S-ratio of 2 . There will be a difference between the leaching from the two alternative roads in both cases. Since the leachate from the landfill is assumed to be treated within the landfill in a short-term perspective, only the leaching from the road construction has been considered in these figures to enable the comparison.

In an infinite-time perspective all available metals and As can be assumed to leach out from the crushed rock and the MSWI bottom ash, regardless if the material is situated in a landfill or in a road. If leaching from the whole system is considered instead of only the leaching from the road (including the leaching from the landfill), and if the available content is used for the comparison, there would be a little relative difference in leaching between the alternatives (fig 5c). 

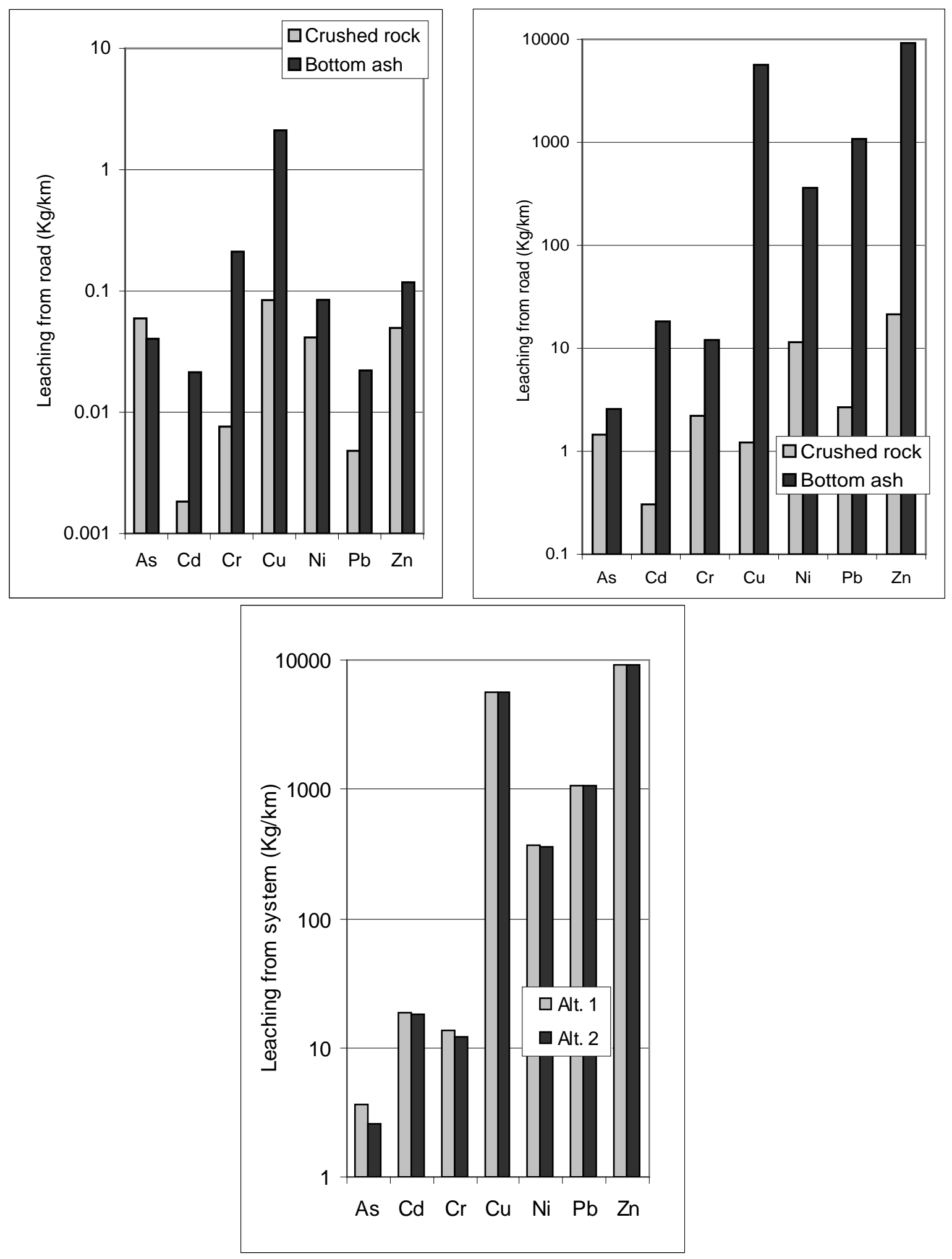

Fig. 5. Upper left: Leaching from the sub-base and base course layers (kg/km road) estimated from data obtained by CEN tests using a liquid-solid ratio of 2 for bottom ash (RVF, 2002) and for crushed rock (Tossavainen et al., 1999). 
Upper right. Leaching from the sub-base and base course layers ( $\mathrm{kg} / \mathrm{km}$ road) estimated from data on the potentially available metals in the bottom ash (RVF, 2002) and in the crushed rock (Tossavainen et al., 1999).

Lower: Leaching from the alternatives (including both sub-base and base course layers in the road and the landfill) (kg/km road) estimated from data on the potentially available metals in the bottom ash (RVF, 2002) and in the crushed rock (Tossavainen et al., 1999).

\section{Discussion}

\subsection{Difference in environmental aspects}

As shown above, the studied alternatives are associated with different environmental aspects. Usually leaching of metals is the only aspect considered in environmental assessments of alternative material. According to the normalized results it is reasonable to consider contaminant leaching as an important aspect, but it may be inadvisable to neglect the other consequences of the substitution of material. The difference in environmental performance between the alternatives is also strongly dependent on the use of energy and the use of natural aggregates. The same aspects, especially the energy use, have been considered as important also in previous lifecycle based studies on the use of alternative material in road constructions (Mroueh et al., 2001; Birgisdottir, 2005). Whereas the resource use occurs mainly during the construction and the landfilling stage of the life cycle, the leaching occurs during the use of the road. Any further attempt to increase the accuracy of the results should emphasize those three aspects and the parameters that affect them. 4.2 Important parameters 
The balance between the alternatives may change if the energy use in the different life cycle stages has been incorrectly estimated, or if assumptions of leaching are shown to be wrong. The parameters that have an impact on those aspects are therefore important. As shown above, a long transporting distance for MSWI bottom ash may, for example, change the balance between the alternatives such that alternative 2 has the larger energy use.

Besides the energy use, differences in contaminant leaching between the two alternatives were shown to be significant for the comparison. Cadmium, chromium and copper were the three most important metals according to the normalized results. The larger arsenic leaching from crushed rock than from MSWI bottom ash when measured by the CEN-test may be due to a large content of arsenic in the rock material, see e.g. Qvarfort (1992). The reason for the comparatively low arsenic leaching measured by the availability test may be that arsenic is strongly bound to iron and aluminum oxides at the acid test conditions (Smeadley et al., 2002). The results from CEN tests and availability tests were used as a basis for approximation of accumulated leaching during different time perspectives. The difference in results from these tests implies that the time frame used for leaching scenarios will be influential in determining the differences in leaching between the alternatives.

Since leaching data in this study are based on laboratory experiments, and since conditions during these experiments may be different from the actual conditions in the road, the results should be interpreted with care. In a study by Fällman and Rosén (2001) significant differences were found between leaching from MSWI bottom ash 
measured in column experiments and measured in lysimeter experiments in the field. There are several reasons for being cautious when using the results from CEN-tests and availability tests as an assumption of leaching during field conditions. Firstly, the infiltrating water may contain a certain amount of contaminants, salts and organic material, which may influence the leaching patterns. For example, leaching of $\mathrm{Cu}$ from MSWI bottom ash has been shown to be controlled by the availability of strong organic ligands (Meima et al., 1999). Secondly, the MSWI bottom ash in the road body may not be water-saturated, at least not all the time, as is the case during the leaching tests. As shown by previous studies, changing wet and dry periods may influence the precipitation and redistribution of contaminant concentrations in pore water (Garrabrants et al., 2002), and may therefore affect the leaching from a material. The redox potential has also been shown to affect the leaching behavior of different metals (Fällman et al., 1994; Fällman, 1997).

\subsection{Outlined approach}

The ESA approach outlined here was shown to be a useful tool for describing the different kinds of environmental aspects associated with the studied alternatives. It included not only the use stage of the life cycle where the leaching of metals occurred but also the production-of-material stage and construction stage where most energy was used and most emissions to air took place. Hence, the ESA approach allowed both resource use and emissions to be considered, thereby giving a different result than a narrower study including only the use stage of the life cycle.

However, the approach showed some limitations in those environmental aspects that are strongly related to the time frame used, such as contaminant leaching. It can be 
argued that leaching on an infinite time scale is of limited interest, since the environmental impact from metals is often due to peaks in concentrations, rather than average emissions. Even a time perspective of 50 or 100 years may be inaccurate. Since an ESA deals with all environmental loads that a system will cause independently of spatial resolution or time, the dose-response is not considered. For correct environmental assessments in specific road projects, the results from this study should therefore be complemented with more local impact assessments that emphasize the dose-response in the area of interest. Previously developed frameworks for risk assessments and critical limit definition that are based on geochemical modeling, field verification and toxicity estimations (i.e. Kosson et al., 2002; Petkovic et al., 2004) should be useful for this purpose. Different levels of uncertainty in contaminant release estimates may be incorporated according to Apul et al. (2003).

This study dealt with a theoretical case in the Stockholm region, and the amounts of emissions released and resources used are case specific. For example, leaching predictions are based on L/S ratios and they therefore depend on the specific amount of MSWI bottom ash material used, the precipitation in the Stockholm region and the estimated water infiltration through the road body. Thus, the results from this study may not be valid for other areas with different climates and leaching conditions.

It should be noted that this study has examined only two different alternatives for the disposal of MSWI BA. There are also other possibilities, which have not been investigated. The MSWI bottom ash can, for example, be used within the disposal area to cover other, more environmental hazardous, materials. This application is likely to increase in importance in the future. There are also other possible secondary 
materials that may be used for road construction and for which an ESA similar to the one used in this study may provide valuable information. For cases in which other alternatives (regarding type of construction and material) are to be analysed, the LCAbased ESA approach outlined here may serve as an example but needs further adoption.

\section{Conclusions}

The results of the studied case showed that the use of MSWI bottom ash instead of crushed rock in the sub-base layer of a road would lead to less energy use and less energy-derived emissions. On the other hand, the leaching of some metals $(\mathrm{Cd}, \mathrm{Cr}$, $\mathrm{Cu}, \mathrm{Ni}, \mathrm{Pb}$ and $\mathrm{Zn}$ ) can be expected to be larger from the road if MSWI bottom ash is used. Parameters with the potential to change these results are the transport distance for the material and the conditions affecting contaminant leaching. It should be emphasized that the results depend on several assumptions and estimates used in the case; in particular the leaching estimates are uncertain. Therefore, further research is needed on hydrological conditions in roads and leaching mechanisms of the material in the road under field conditions.

This study also demonstrates how an ESA method can be used to obtain information for strategic decision support, i.e. SEA, concerning waste management. The investigated life cycle stages of the road were associated with different environmental aspects. The energy use occurred mainly in the production-of-material stage and the disposal stage while the metals were leached during the use stage. This implies that it 
is important to include all these life cycle stages in studies that aim at evaluating the environmental impact of MSWI bottom ash in constructions.

\section{Acknowledgements}

Formas and J Gust Richert Foundation are acknowledged for financial support.

\section{References}

Andersson, A., Andersson, G., Andréasson, J., et al., 2003. Energiläget 2003. ET 20:2003; Statens energimyndighet, Eskilstuna, Sweden.

Apul, D.S., Gardner, K.H. and Eighmy, T.T., 2003. A probabilistic source assessment framework for leaching from secondary materials in highway applications. Clean Techn Environ Policy, 5: 120-127.

Arm, M., 2003. Mechanical Properties of Residues as Unbound Road Materials. Doctoral thesis, Royal Institute of Technology (KTH), Stockholm, Sweden.

Bergbäck, B., Johansson, K. and Mohlander, U., 2001. Urban metal flows - a case study of Stockholm. Water, Air, and Soil Pollution: Focus, 1: 3-24.

Birgisdottir, H., 2005. Life cycle assessment model for road construction and use of residues from waste incineration. Doctoral thesis, Technical University of Denmark, Kgs. Lyngby, Denmark.

Björklund, A., 1998. Environmental systems analysis of waste management. Licentiate thesis, Royal Institute of Technology (KTH), Stockholm, Sweden.

Björklund, A., Dalemo, M. and Sonesson, U., 1999. Evaluating a municipal waste management plan using ORWARE. Journal of Cleaner Production, 7: 271280.

Bruder-Hubscher, V., Lagarde, F., Leroy, M.J.F., et al., 2001. Utilisation of bottom ash in road construction: evaluation of the environmental impact. Waste management and research, 19: 545-556.

Brånvall, G. and Widell, A., 2002. Utsläpp till vatten och slamproduktion 2000 kommunala reningsverk samt viss kustindustri. Sveriges officiella statistik, Statistiska meddelanden MI 22, SM 0101; Naturvårdsverket och SCB, Stockholm, Sweden.

Chandler, A.J., Eighmy, T.T., Hartlén, J., et al., 1997. Municipal Solid Waste Incinerator Residues. Studies in Environmental Science 67; IAWG (International Ash Working Group), Elsevier Science, Amsterdam, The Netherlands.

Feldhusen, K., Hammarskjöld, G., Mjureke, D., et al., 2004. Sweden's National Inventory Report 2004 - Submitted under the United Nation Framework Convention on Climate Change. Swedish Envrionmental Protection Agency, Stockholm, Sweden. 
Finnveden, G., Johansson, J., Lind, P., et al., 2005. Life cycle assessment of energy from solid waste - part 1: general methodology and results. Journal of Cleaner Production, 13: 213-229.

Fällman, A.-M., 1997. Characterisation of residues - Release of contaminants from slags and ashes. Doctoral thesis, Linköping University, Linköping, Sweden.

Fällman, A.-M. and Hartlén, J., 1994. Leaching of slags and ashes - controlling factors in field experiments versus in laboratory tests. In: J. J. J. M. Goumans, H. A. van der Sloot and A. Th.G. (Ed.), Environmental Aspects of Construction with Waste Materials. Vol 60. Elsevier, Amsterdam, The Netherlands, pp. 39-54.

Fällman, A.-M. and Rosén, B., 2001. Leaching from Slags and Ashes in Lysimeters. In: T. T. Eighmy (Ed.), Beneficial Use of Recycled Materials in Transportation Applications, 13-15 November 2001, Virginia. Air \& Waste Management Association. pp. 355-364.

Garrabrants, A.C., Sanchez, F., Gervais, C., et al., 2002. The effect of storage in an inert atmosphere on the release of inorganic constituents during intermittent wetting of a cement-based material. Journal of Hazardous Materials, B91: 159-185.

Hammarskjöld, G., Staaf, H., Adolfsson, R., et al., 2004. Emission Data Report 2004 Submitted under the Convention on Long-Range Transboundary Air Pollution. Naturvårdsverket, Stockholm, Sweden.

Hartlén, J., Grönholm, R., Nyström, T., et al., 1999. Återanvändning av sekundära material inom anläggningsområdet. AFR-report 275; AFN, Naturvårdsverket, Stockholm, Sweden.

ISO, 1997. Environmental Management - Life Cycle Assessment - Principles and Framework. International Standard ISO 14040.

Kosson, D.S., van der Sloot, H.A., Sanchez, F., et al., 2002. An Intergrated Framework for Evaluating Leaching in Waste Management and Utilization of Secondary Materials. Environmental Engineering Science, 19: 159-204.

Meima, J.A. and Comans, R.N.J., 1999. The leaching of trace elements from municipal solid waste incinerator bottom ash at different stages of weathering. Applied Geochemistry, 14: 159-171.

Meima, J.A., van der Weijden, R.D., Eighmy, T.T., et al., 2002. Carbonation processes in municipal solid waste incinerator bottom ash and their effect on the leaching of copper and molybdenum. Applied Geochemistry, 17: 15031513.

Meima, J.A., van Zomeren, A. and Comans, R.N.J., 1999. Complexation of Cu with Dissolved Organic Carbon in Municipal Solid Waste Incinerator Bottom Ash Leachates. Environ. Sci. Technol., 33: 1424-1429.

Mingarini, K., 1996. Systems Analysis of Organic Waste - with Emphasis on Modelling of the Incineration and the Landfill Processes. Licentiate Thesis, Royal Institute of Technology (KTH), Stockholm, Sweden.

Mroueh, U.-M., Eskola, P. and Laine-Ylijoki, J., 2001. Life-cycle impacts of the use of industrial by-products in road and earth construction. Waste Management, 21: 271-277.

Mroueh, U.-M., Eskola, P., Laine-Ylijoki, J., et al., 2000. Life cycle assessment of road construction. 17; Finnish National Road Administration, Helsinki, Finland.

Olsson, S., 2005. Environmental assessment of municipal solid waste incinerator bottom ash in road constructions. Licentiate thesis, KTH, Stockholm, Sweden. 
Petkovic, G., Engelsen, C.J., Haoya, A.-O., et al., 2004. Environmental impact from the use of recycled materials in road construction: method for decision-making in Norway. Resources, Conservation and Recycling, 42: 249-264.

Qvarfort, U., 1992. The high occurence of arsenic in macadam products from an iron mine in central Sweden: significance for environmental contamination. Environmental Geochemistry and Health, 14: 87-90.

Roth, L. and Eklund, M., 2003. Environmental evaluation of reuse of by-products as road construction materials in Sweden. Waste Management, 23: 107-116.

RVF, 2002. Kvalitetssäkring av slaggrus från förbränning av avfall. 02:10; Svenska Renhållningsverksföreningen, Malmö, Sweden.

SETAC-Europe, 1999. Best Available Practice Regarding Impact Categories and Category Indicators in Life Cycle Impact Assessment. Int. J. LCA, 4: 167-174.

SGU, 2003. Grus, sand och krossberg, produktion och tillgångar 2002. 4; SGU, Uppsala, Sweden.

Smedley, P.L. and Kinniburgh, D.G., 2002. A review of the source, behaviour and distribution of arsenic in natural waters. Applied Geochemistry, 17: 517-568.

Stripple, H., 2001. Life Cycle Assessment of Road, A Pilot Study for Inventory Analysis. Second revised edition, B1210E; IVL Svenska Miljöinstitutet AB, Göteborg, Sweden.

Sundqvist, J.-O., Finnveden, G. and Stripple, H., 1997. Life Cycle Assessment and Solid Waste - Stage 2. 173; Swedish environmental protection agency, Stockholm, Sweden.

Tillman, A.-M., Baumann, H., Eriksson, E., et al., 1991. Livscykelanalyser för förpackningsmaterial - Beräkning av miljöbelastning. Statens offentliga utredningar 1991:77; Miljödepartementet, Sweden.

Tossavainen, M. and Forssberg, E., 1999. The potential leachability from natural road construction materials. The Science of the Total Environment, 239: 31-47.

Tossavainen, M. and Håkansson, K., 1999. Reference data of leaching of natural materials and effects on its leaching properties of ageing. AFR-Report 254; AFN, Naturvårdsverket, Stockholm, Sweden.

Wiles, C.C., 1996. Municipal solid waste combustion ash: State-of-the-knowledge. Journal of Hazardous Materials, 47: 325-344. 